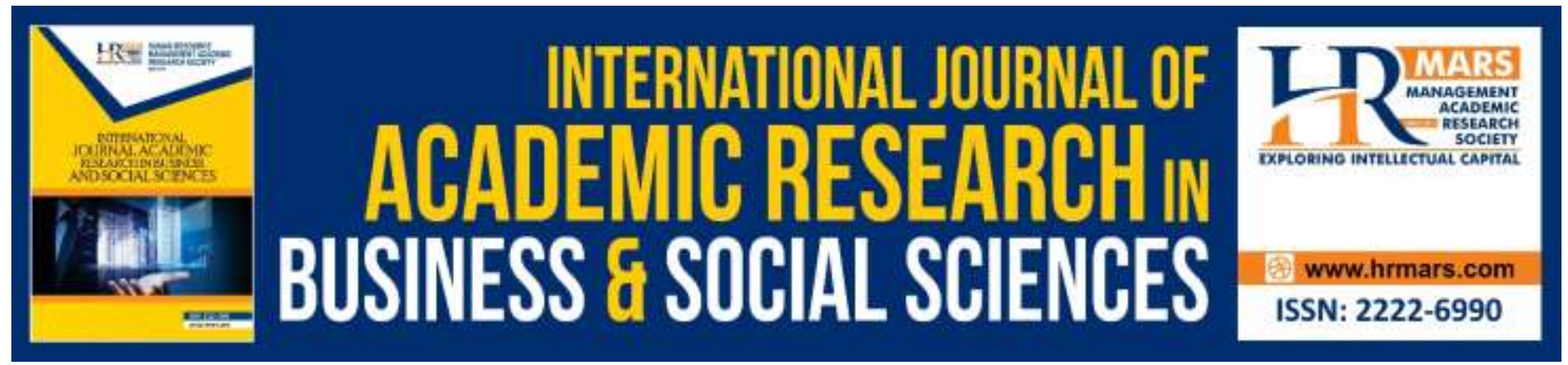

\title{
The Message in the Preaching to Chieftains and Its Appropriateness: An Example of Preaching To Chieftains in the Malay Archipelago
}

Zawawi Yusoff, Fadzli Adam, M. Zaidin Mat, Roslan Abd Rahman

To Link this Article: http://dx.doi.org/10.6007/IJARBSS/v9-i11/6605

DOI: 10.6007/IJARBSS/v9-i11/6605

Received: 09 October 2019, Revised: 28 October 2019, Accepted: 05 November 2019

Published Online: 22 November 2019

In-Text Citation: (Yusoff, Adam, Mat, Rahman, 2019)

To Cite this Article: Yusoff, Z., Adam, F., Mat, M. Z., Rahman, R. A. (2019).The Message in the Preaching To Chieftains and Its Appropriateness: An Example of Preaching To Chieftains in the Malay Archipelago. International Journal of Academic Research in Business and Social Sciences, 9(11), 851-863.

Copyright: (C) 2019 The Author(s)

Published by Human Resource Management Academic Research Society (www.hrmars.com)

This article is published under the Creative Commons Attribution (CC BY 4.0) license. Anyone may reproduce, distribute, translate and create derivative works of this article (for both commercial and non-commercial purposes), subject to full attribution to the original publication and authors. The full terms of this license may be seen

at: http://creativecommons.org/licences/by/4.0/legalcode

Vol. 9, No. 11, 2019, Pg. 851 - 863

http://hrmars.com/index.php/pages/detail/IJARBSS

JOURNAL HOMEPAGE

Full Terms \& Conditions of access and use can be found at http://hrmars.com/index.php/pages/detail/publication-ethics 


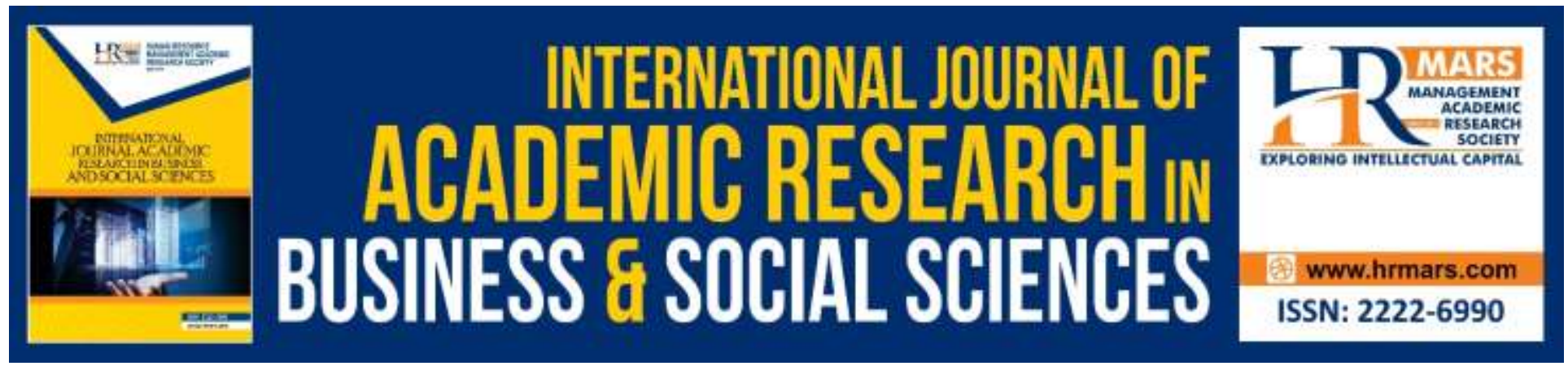

\title{
The Message in the Preaching to Chieftains and Its Appropriateness: An Example of Preaching To Chieftains in the Malay Archipelago
}

\author{
Zawawi Yusoff, Fadzli Adam, M. Zaidin Mat, Roslan Abd Rahman \\ Faculty of Islamic Contemporary Studies, Universiti Sultan Zainal Abidin, MALAYSIA
}

\author{
Moohamad Khoya \\ Fatoni University, THAILAND
}

\begin{abstract}
Successful preaching depends on several factors, such as choosing an appropriate message and the appropriateness of its contents or mawduk with the target of the preaching. One of the target groups is the chieftains or mentioned in the al-Quran as the mala'. This group occupies the highest position in the social system hierarchy of a society or group and it usually holds the reins of power as well as being very influential. During the time of the Prophet SAW and the beginning of preaching in the Malay Archipelago, preaching disseminated quickly because it was supported by this group. The spread of Islam throughout the Malay Peninsula is evidence of this fact. This shows that the dissemination and expansion of Islam throughout the Malay Peninsula started with the chieftains and it quickly spread among the public. The paper found the influence held by the chieftains had made them one of the main target groups of the preachers. This success was the main factor responsible for the expeditious dissemination of Islam, either inside or outside the Arab Peninsula. The need and importance of preaching to the chieftains is evident when examining the coming and dissemination of Islam throughout the Malay Archipelago.
\end{abstract}

Keywords: Message, Preaching, Malay, Archipelago

\section{Introduction}

Successful preaching depends on several factors, such as choosing an appropriate message and the appropriateness of its contents or mawduk with the target of the preaching. This was apparent in the preaching practices of the Prophet SAW, who sometimes gave different answers to the same question or almost similar question. For example, when the Prophet SAW was asked 
by various people about the best practices or the most liked by Allah SWT, the answer to three of them was slightly varied (Zin, 1999). This was because the target of the preaching consisted of various groups. Each group commanded an appropriate message as well as approach and a method (us/ub) consistent with their level of ego or relationship that can penetrate their conscience and thinking. The message or mawduk, approach, method (uslub) and relationship (wasilah) would greatly help if the preacher can understand and identify the background of each target group from various aspects. Ignorance of the target group's identity is a constraint usually faced by preachers (Yusoff, 2016; Aziz \& Mamat, 2018).

One of the target groups is the chieftains or mentioned in the al-Quran as the mala'. This group occupies the highest position in the social system hierarchy of a society or group and it usually holds the reins of power as well as being very influential. During the time of the Prophet SAW and the beginning of preaching in the Malay Archipelago, preaching disseminated quickly because it was supported by this group. The spread of Islam throughout the Malay Peninsula is evidence of this fact. This shows that the dissemination and expansion of Islam throughout the Malay Peninsula started with the chieftains and it quickly spread among the public. Their acceptance of preaching had a big impact on the success of the preaching itself and vice versa. The influence of the chieftains had made preaching very important; however, this was difficult because preaching is related to leadership, which is directly related to power. Meanwhile, power is a specific characteristic of the chieftains; it is like there is a clash between the two. The ultimate importance of preaching to them could be better understood through the practices of the Prophet SAW. Since the beginning of preaching in Mecca, the Prophet SAW was concerned about this group and HE thought of it as a preaching strategy that could be a success factor in HIS preaching (Barghuth, 1996; Fery, 2018). The main factor that prompted the successful expansion of preaching was the role played by this group. The evidence is that they formed the majority of early Muslims who were the core of the preaching movement (Shakir, 1991). It was similar in Madinah too, whereby in efforts to realise the popularity of preaching, the Prophet SAW had preached to the chieftains from Arab and non-Arab countries by using the manhaj murasalah (AlSallabi, 2004).

\section{Concept of the Message}

According to Zaydan, the message contained in the preaching is the teaching of Islam itself, which was divinely revealed by Allah SWT to the Prophet Muhammad SAW as contained in the al-Quran and al-Sunnah (1991). Whereas, according to al-Rumi (2008), the message contained in the preaching is the contents adduced by preachers to their target group so that the target group understands and becomes their students. Hence, the message and contents of preaching is very wide, encompassing the whole of Islam itself, which is made up of various sections and perspectives, either related to faith (akidah), syariat or morality (akhlak) (Ghalush, n.d; Zaydan, 1991; Al-Bayanuni, 1993; Mahmud, 1993).

Preaching, as a discipline of knowledge, has its own contents, just like other disciplines of knowledge. As for 'Abd al- 'Aziz Barghuth, he had divided the views of researchers concerning the contents of preaching into two groups. The first group was of the view that the contents of 
knowledge aimed to examine Islam and all its teachings as well as its method of deliverance. Whereas the second group was of the view that the contents of preaching aimed to examine humankind and society as well as methods for delivering the teachings of Islam to them (Barghuth, 2005).

Based on the preaching by fellow Messengers (Rasul a.s.) to the Chieftains, as mentioned in the al-Quran and books on Sirah, it can be concluded that among the messages or subject matter of the preaching to the Chieftains (Yusoff et al., 2016) were:

1. Confirmation of Allah SWT's existence with proof concerning the process of life and death, whereby there is no life or death without the existence of the ONE that gives or takes life. Surah al-Baqarah (2): 258.

2. Confirmation of Allah SWT's Divinity (rububiyyah) above ALL (mawjudat) else. Surah alShu 'ara' (26): 24.

3. Confirmation of Allah SWT's prowess, which gives life and death to every human body. Surah al-Baqarah (2): 258.

4. Confirmation of the capabilities of Allah SWT. Surah Taha (20): 50-53.

5. Confirmation of the existence of Allah SWT with al-Rahman and al-Rahim attributes. Surah al-Naml (27): 30.

6. The call to recognise the monotheistic nature of Allah SWT in religious practices (ibadah) and reject all forms of idolatry inherited from ancestors (Ibn-Hisham, 2004).

7. Confirmation of the Messengers through verbal confession and proof based on miracles (mukjizat). It contains the meaning of preaching the message (al-risalah), which refers to the message that comes from Allah SWT, the God of the Universe. Surah al-A 'raf (7): 104-105, Surah al-Zukhruf (43): 46-47, Surah Taha (20): 47 and Surah al-Shu 'ara' (26): 16.

8. Instruction to accept Islam by condescending and being obedient to the commands of Allah SWT. Surah al-Naml (27): 31.

9. Shows how weak creatures are no matter how high their position. Thus, creatures are not fit to be worshiped but it is mandatory to worship Allah SWT, who gives and takes life. Surah al-Baqarah (2): 258.

10. The call to carry out specific religious practices, such as prayers (solat), alms (zakat) and fasting (Ibn Hisham, 2004).

11. Shows that the grace of Allah SWT in the form of blessings is far better than wealth, no matter how much. Surah al-Naml (27): 36.

12. A guarantee of safety and well-being in this world and the after-world for those who follow the commands of Allah SWT. Surah Taha (20): 47.

13. The threat of torment in this world and the after-world to those who lie about the verses of Allah SWT and practise polytheism. Surah Taha (20): 48.

14. The threat of war if one opposes preaching. Surah al-Naml (27): 37.

15. The call for them to be humble when dealing with society by speaking the truth, fulfil the trust, nurture good relationships, honour guests and avoid forbidden acts as well as bloodshed (Ibn-Hisham, 2004). 
16. Prohibited from carrying out despicable acts, being dishonest, usurping the property of orphans and slandering sacred women (Ibn-Hisham, 2004).

17. Prohibited from being overly arrogant, which could prevent one from accepting the truth or capitulating to one's natural inclinations (hawa nafsu). Surah al-Naml (27): 31.

\section{Compatibility of the Message with the Target}

As the message and contents of the preaching vary widely, so too the target group of the preaching; hence, the message and the target must be synchronised. This means that the preacher should choose specific messages that are appropriate when considering the target (Zin, 2005).

In order to explain the need for choosing appropriate messages when preaching according to the target group, Ab. Aziz quoted several clarifications by leading preachers as well as the practices of the Prophet SAW.

Yakan (1977) explained that based on the situation and the various habits of the target group, each preacher must be well-informed about the target group, how it thinks, its understanding, what are its problems as well as obstacles that the preacher might encounter. Being aware of all these elements would help to achieve necessary solutions.

Zaydan (1991) explained that a successful preaching method begins by identifying the problems faced by the target group and then, determining a solution for the problems.

Al-Wakil (1994) stated that the preacher must choose a suitable message that can help solve the problems of the target group by adducing suitable solutions until the target group realises that the preaching contributes massively towards their life with no other solution in sight.

When Ja'far ibn Abi Talib and his entourage were migrating to Ethiopia from Mecca, which was before the Hijrah by the Prophet SAW to Madinah, Ja'far ibn Abi Talib had a meeting and alNajashi, the King of Ethiopia. Al-Najashi asked him to adduce any one of the explanations from Allah SWT revealed to the Messenger he mentioned. Hence, Ja 'far ibn Abi Talib recited Surah Maryam (the beginning of Surah Maryam talks about Prophet Jesus a.s.). After listening to the recital, al-Najashi cried and then said that the meaning of the Surah was, "surely Allah SWT had sent the Prophet Jesus a.s., and verily this (the religion brought by Prophet Muhammad SAW) came from the same place (as the religion brought by the Prophet Jesus a.s.). The wisdom of Ja 'far ibn Abi Talib in choosing Surah Maryam to be recited to al-Najashi was because the King was a Christian. Hence, Ja 'far ibn Abi Talib had used the correct method in his preaching (Abu Zahrah Muhammad (c), (t.t).

Pertaining to his matter, Sayidina 'Ali (KW) conveyed the following message: (Ibn-Hajar, 1989).

$$
\text { حدثوا الناس بما يعرفون ، أتحبون أن يكذب الله ورسوله؟ }
$$

Meaning:

Talk to others based on their understanding (according to what they are capable of understanding). Do you like Allah SWT and HIS Messenger to be lied upon? 
This message means that the preacher should examine the target group in order to ensure that the preaching is suitable or compatible with the respective target group. He should not adduce his preaching according to his wishes prior to adapting it with the target group's current situation.

These explanations show that the target group's situation must be considered when using the correct message in the preaching so that it can be understood, be attractive and influential.

In a hadith narrated by Ibn 'Abbas, the Prophet SAW advised Mu'adh ibn Jabal by iterating: (Ibn-Hajar, 1989, Baltaji, 1993).

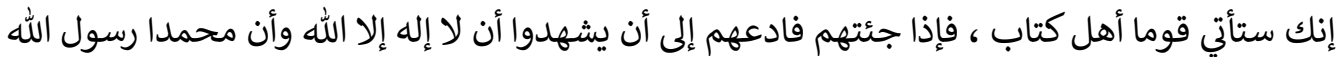

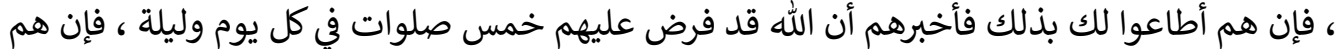

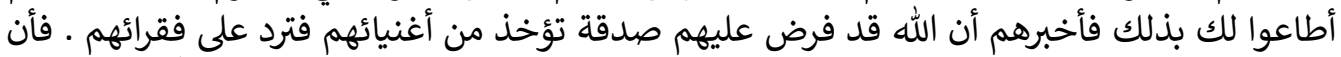

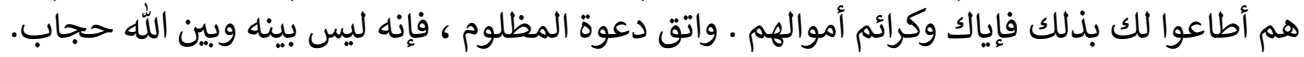

\section{Meaning:}

Verily you will be approached by a group of members of the scripture (Christians and Jews). When they reach you, plead with them to profess the Kalimah Syahadat. When they accept and implement the plea, then tell them that Allah SWT has made it obligatory onto them to perform prayers (solat) five times a day. Next, when they have abided by that call, tell them that Allah SWT also made it obligatory onto them to pay alms (zakat), which is collected from the rich to be given to the poor. Next, take care not to usurp their property. Fear the invocation (dua) of those who have been victimised because nothing can block the invocation from Allah SWT.

According to the hadith above, the Prophet SAW had very briefly explained to Mu'adh about the society's belief in the faith delivered by HIM so that they will know who HE is and be prepared so that HE knows what to give as well as what is best for society.

Generally, the suitability of the message in the preaching contains three elements: (Zin, 2005).

1. Suitability with the current religion and principles of life.

2. Suitability with the level of the target group.

3. Suitability with the current problems faced by the target group.

Hence, from another perspective, the approach of the message can be basically divided into two, namely the approach for non-Muslims and Muslims. The approach of the message for non-Muslims centres on three elements (Zin, 2005).

1. Building trust on the contents of the message.

2. Building basic trust.

3. Eliminating the obscurity and problems faced by the target group. 


\section{The Chieftain Concept}

As mentioned in the title of this article, the word 'chieftain' (mala') according to linguists generally refer to an influential person and a person who acts as a reference to others. Usually this person is an elite, chief, leader, authority etc. to a group of humans, either officially or unofficially. According to linguists, some of the characteristics of a chieftain are humility (Abu-alDahab, 2002), a high social standing, having a sense of welfare and pithy opinions (Abu-Haqah, 2007) possess capabilities and riches (Al-Bustani Butrus, 1869), possess a position and rank (Majma' al-Lughah al-'Arabiyyah, 1970), admired (al-Raghib, (n.d.), outstanding, eminent and can achieve his ambitions (Al-Zamakhshari, 1992), and a place of reference (Ibn-Manzur, 1990). Whereas, according to an interpreter of the scriptures, the characteristics of a chieftain are humility (Haqqi, (n.d), being impressive and helpful (al-Alusi, n.d), and can fulfil the realities of life (Al-Sha'rawi, n.d.).

Hence, by possessing these characteristics, chieftains are very influential and respected. They are associated with power, which is an element that is cherished by humans as a part of human nature. Therefore, it is important to view the position of a chieftain from the aspects of social status, habit as well as views about power and Islam.

\section{The Malay Archipelago (Nusantara)}

According to Zainal Kling, the Malay Archipelago, which is a cultural term, generally refers to a geographical area that practices the Malay culture and consists of not less than 200 million inhabitants who communicate using the Malay language family and adopt different customs and traditions (1991).

From a contemporary geo-political aspect, territories that make up the Malay Archipelago consists of Malaysia (includes the territory of South Thailand, which is not an island but part of South East Asia, beginning from the Isthmus of Kra and joins the Malaysian Peninsula with the Asian continent), Indonesia, Singapore and the Philippines.

\section{Preaching to Chieftains in the Malay Archipelago}

Location of the Malay Archipelago between the Indian continent and the Chinese mainland makes it a place where culture as well as western and eastern influences meet and merge. The group of islands between the Pacific and Indian Oceans act as a natural port. The expansion of trade created kingdoms along the coastlines and eventually thinking, culture and religion also expanded and developed. The local community that subscribed to ancient beliefs as well as spirit and soul worshipping were exposed to religions from the outside, especially Hinduism and Buddhism. Early kingdoms that thrived in the Malay Archipelago, such as Old Kedah, Langkasuka, Singasari and Kalinga, have been influenced by both, local beliefs and Hinduism (Yahaya, 1983/84).

The influence of Buddhism and Hinduism had reached its climax during the era of the Majapahit empire (Legge, 1972); however, Islam had the biggest influence in reshaping the landscape of the Malay Archipelago (Hamka, 1981). Although Hinduism and Buddhism during the Srivijaya era (Shuhaimi, 1979/80) were already well established in the Malay Archipelago for 
several centuries (Hashim, 1992), Islam had succeeded in taking over and gradually changing the view of life of inhabitants living there. Presently, Islam has the largest following in South East Asia with approximately 250 million followers, which is almost equivalent to the number of Muslims in the Arab countries.

According to Noor (2007), the Orientalists had tried to deny the role of preachers played by full-time preachers and missionaries who came from the Arab World with the aim of preaching in the Malay Archipelago. They gave the impression that Islam in the Malay Archipelago only expanded through the assimilation process, whereby the local community gradually accepted Islam after mixing with Muslim merchants. In order to succeed in their efforts, they had emphasised on several theories concerning the expansion of Islam in the Malay Archipelago, such as the merchant, politics, marriage and competition theories. The views of Syed Muhammad Naquib al-Attas, who claimed to possess strong evidence that Islam was brought to the Malay Archipelago directly by a mission from the Arab World, perhaps could consolidate the opinions of Hafidzi. According to al-Attas (2011), the group that brought Islam not only inspired humans to embrace Islam but also established an Islamic Dynasty that eventually became a regional preaching hub. The author is of the view that theories concerning the expansion of Islam, as adduced by the Orientalists, were not wrong but the denial of the role played by preachers, such as full time preachers and missionaries who specifically came from the Arab World with the aim of preaching in the Malay Archipelago, is not true. This is because the theories cannot discount the role of full-time preachers but instead prove that the preachers had adhered to the correct manhaj, especially in relation to preaching to chieftains.

When comparing the Islamic expansionism in the Arab World and Africa, the expansion of Islam in the Malay Archipelago was far different. In the former, Islam expanded through preaching and not through conquest; therefore, it was accepted open heartedly by most of the local communities (Mohamad et al., 2001). Generally, history shows that the preaching process in the Malay Archipelago occurred smoothly without much hindrance from the rulers or aristocrats (chieftains). Azmi (1980) stated that this occurred because Arab merchants had good relations with the local rulers. Another factor was the fortitude shown by the ulama, missionaries and $d a^{\prime} i$ who preached Islam throughout the Malay Archipelago until they succeeded in "Islamising" the Malay rulers, such as Meurah Silu (Raja Pasai), Parameswara or Megat Iskandar Shah (Melaka) and Raja Kedah. Consequently, the Islamisation of these rulers had caused a mass conversion of the population to Islam. The climax was the birth of Islamic kingdoms such as Samudera-Pasai, Melayu Melaka, Demak, Ternate and Aceh. Mahayudin Hj. Yahaya commented as follows: (Yahaya, 2001).

"Islam was once a basis of governance in the Malay world. Beginning in the $15^{\text {th }}$ century, the glamour of the Islamic-Malay Sultanate comprising Melaka, Johor, Pahang, Perak, Kedah, Kelantan etc. was centred on Islamic governance. The governance, legislation, commerce, education and social life systems were all based on Islamic teachings. The fame and glory of the Malay world as an International Commercial Centre and a Centre for the 
Dissemination of Islam was famous even across Europe. Hence, the great powers of the West raced to the East, specifically to the Malay Archipelago to reap the riches."

This scenario proves that preachers played a big role in the Islamic expansion process throughout the Malay Archipelago, especially their success in 'Islamising' the chieftains. It can be concluded that the preachers had been successful in their mission to preach, especially among the chieftains. The success was surely based on the correct preaching method besides employing a message in the preaching that was suitable with the target group (suitable with the political and competitive theories). Therefore, the Malay Rulers were able to easily accept their preaching and Islam had expanded among the people.

\section{Preaching to Parameswara, the Ruler of Melaka}

Parameswara was a prince from Palembang who had married the sister of Batara Tamarill, the King of Majapahit. Parameswara had launched a revolt to free his territory from the reigns of the Majapahit when a political crisis occurred between the rulers of Majapahit in 1389. Consequently, Palembang was attacked by the Majapahit army in 1397 and Parameswara was forced out of Palembang. He then absconded to Singapore (Temasik) and killed the Siamese ruler, Temagi. Having lived there for a few years, Parameswara and his followers were then again forced out by the Siamese army that came from Ayuthia. Parameswara quickly fled to Melaka and opened up a settlement there (Cortesao, 1944).

According to Ra'uf Shalabi in his book al-Islam fi Arkhabil al-Malaya, Parameswara had embraced Islam at the end of the fourth century after he was preached by a famous ulama from Jeddah, al-Sayyid 'Abd. al-'Aziz. Since then Melaka had become a centre (daulah) of Islam (1983). The story of Parameswara's proselytization (Islamisation) is mentioned in Malay History as follows; (Ahmad, 1986).

....after Asar there came a ship from Jeddah, and it docked; there exited the makhdum (the title given by the Malays to the ulama') from the ship, Syed Abdul Aziz was his name, then he performed the prayers on the Melaka beach. The people of Melaka were surprised to see him. Then they said, "Why is he bending over like that?". They all scrambled and jostled to witness the event. Hence, the Ruler hurried onto his elephant to witness the event escorted by his chieftains. He saw the makhdum performing the prayers, which was what he saw in his dream. The Sultan then said to the vizier and other chieftains, "this is clearly what happened in my dream". After the makhdum had performed his prayers, the Ruler got on his elephant along with the makhdum and took him to his state. Then all the chieftains embraced Islam as well as all the inhabitants of the state, men and women, young and old, small and big followed suit as commanded by the ruler.

Zubir Usman stated in his book, Melaka dan Sejarahnya: (Khoo Kay Kim (ed.), 1982): According to the history of Melaka, when Parameswara first arrived there were already many Muslims and he eventually became attracted to Islam. Hence, since he realised the significance and prowess of Islam, he quickly embraced Islam and took the name of Iskandar Syah... 
The message in the preaching, as mentioned in the statement above, is evident in examples such as carrying out prayers (solat) and the advantages in the form of added power and strength.

The view which says that the first ruler of Melaka who embraced Islam was Parameswara, actually meant that as a founder, Parameswara (1390-1414) had laid the foundation for an administration that was responsible for turning Melaka into a strong and peaceful government. However, the Melaka government had achieved much more since the acceptance of Islam by its second ruler, Megat Iskandar Syah (1414-1424), who was introduced to Islam by al-Sayyid 'Abd. al-'Aziz from the Arab Peninsula. The Islamisation of Melaka had turned it into a substitute for or at least in par with the prominence of Pasai at that time (Abdullah, 2006).

\section{Preaching to the King of Kedah}

The first King of Kedah to embrace Islam was Maharaja Derbar Raja II, who thereafter changed his name to Sultan Muzaffar Shah I (Hassan, 1963). His embracing of Islam was said to have been solemnised by a preacher from Yemen named Shaykh 'Abd Allah ibn Shaykh Ahmad ibn Shaykh Ja'far Qawmiri al-Yamani in $1136(531 \mathrm{H})$. His embracing of Islam was followed suit by his subjects and chieftains (Yatim \& Nasir, 1990).

The good nature as well as courtesy and behaviour showed by Shaykh 'Abd Allah and his entourage had convinced the Maharaja to allow Shaykh 'Abd Allah to have an audience with him at the palace (Adil, 1980). The audience with the Sultan and his ministers was a sign of confidence that the Maharaja had in Shaykh 'Abd Allah as well as a golden opportunity for Shaykh 'Abd Allah to attract the Maharaja to Islam. Shaykh 'Abd Allah had successfully attracted their interest towards Islam by explaining to them about the virtues and sacredness of Islam (Adil, 1980). Thomas W. Arnold, in his book The Preaching of Islam (1984), stated that Shaykh 'Abd Allah alYamani had visited Kedah and met the Sultan. During the meeting, he asked the Sultan about the religion practiced by his subjects. To this the Sultan replied, "me and my subjects practice the religion inherited from the previous generation, which is idolatry". Then, al-Shaykh asked, "Has Your Highness ever heard about Islam and the al-Quran, which was bestowed by Allah SWT to HIS Messenger, the Prophet Muhammad SAW, whereby renouncing all other previous religions?". The Sultan then said, "If what you say is true, I hope you will teach us this new religion".

Feeling humbled and touched by what the Sultan said, al-Shaykh began to teach Islam to the Sultan. After feeling satisfied with the teachings of Islam, the Sultan instructed all forms of idolatry in the palace to be destroyed. Then, after all his consorts were taught the teachings of Islam, he summoned his four senior chieftains. When they reached the palace, they were shocked to see al-Shaykh sitting beside the Sultan. After the Sultan explained al-Shaykh's mission of preaching, all four chieftains stated their readiness to follow the steps of the Sultan in embracing Islam. Al-Shaykh demanded their sincerity by asking them to persuade the people to bring along their items of worship. Al-Shaykh's call was answered with ease and when all the items of worship had been gathered, they were crushed and burnt.

Based on the transpired above, the message of preaching to the Sultan of Kedah was 
qudwah hasanah, which portrayed the goodness of morality (akhlak) as well as the virtue and purity of Islam and the truth behind the role of the Messengers a.s.

According to Hamka (1980), Merah Silu or Maliku Salih Raja Samudera-Pasai also embraced Islam after listening to the preaching by two preachers, namely Shaykh Isma'il and Fakir Muhammad, who were the descendants of Sayyiduna Abu Bakr al-Siddiq. In addition, Hamka also stated that Raja Tidore Raja Maluku embraced Islam after listening to the preaching by Shaykh Mansur (Abad 16). He said that:

It is mentioned in historical records that King Tidore, whose name was Chirelli Lijatu, did not have any religion and embraced Islam, taking the name of Sultan Jamaluddin due to the pleading by a Sheikh from the Arab World called Sheikh Mansor. This occurred in beginning of the $16^{\text {th }}$ century.

He went on to state that Raja Sukadana (Kalimantan) also embraced Islam after listening to the preaching of Shaykh Shams al-Din and took on the name of Sultan Muhammad Syafiudin. He said that:

It is stated in history that Islam was brought to Sukadana (Kalimantan) by a Sheikh from Mecca whose name was Sheikh Shamsuddin. He brought gifts in the form of the Holy Quran and a Yemeni Aqeeq ring. The Sultan felt honoured by the coming of the Sheikh with his gifts so much so that the Sultan embraced Islam together with all his subjects. He then took an Islamic name, Sultan Muhammad Shafiudin (he passed on in 1677).

Although there are records about the preaching activities carried out to Raja Samudera-Pasai, Raja Maluku and Raja Sukadana (Kalimantan); hence, this study has not found any literature that could help explain the types of messages related to aspect of appropriateness with the target group besides messages of respect. Therefore, this clearly shows that the influence of chieftains on the public.

\section{Conclusion}

Preaching (dakwah), which means efforts by a person or group using a certain approach to help humans to receive the blessings of Allah SWT, is very important and holds a high status in Islam. Hence, the ulama have unanimously agreed that the decree for preaching is mandatory. Since the message and contents of preaching vary widely by covering the whole of Islam, which contains various sections and perspectives and the target of the preaching involves various groups with different backgrounds; hence, each group warrants a message and approach that suits it. One of the target groups is the chieftains. This group occupies the highest rank in the social hierarchy system of a society or community. The chieftains usually hold the echelons of leadership and are revered by citizens or members of the group. Hence, they enjoy various privileges and perks that are earthly in nature and craved by all and difficult to get-by without. By holding such a position, they usually exert influence on all the subordinates, either voluntarily or otherwise. Hence, it can be concluded that the chieftains are the most influential people in a 
community, regardless of whether it is big or small. The al-Quran itself has proven this by relating numerous episodes of conflict amongst chieftains that have instigated the public, either by force or trickery, so that they revolt against the preaching of the Messengers a.s.

The influence held by the chieftains had made them one of the main target groups of the preachers. Thus, if they embraced Islam then some of the obstacles faced by preaching to the ordinary subjects could be overcome. Although the al-Quran explains the difficulty of preaching to the chieftains, which manifests itself in various forms of challenges and tribulations that the Messengers a.s. faced when preaching; however, this did not mean that preaching to them was a futile or grossly unsuccessful effort. Conversely, it was found that preaching to the chieftains was successful and it had a huge impact on the dissemination of Islam in a short period without encountering too many obstacles. It was also evident that during the history of preaching by the Prophet SAW, either in Mecca or in Madinah, where the Prophet SAW had shown his concern for preaching to the chieftains using several successful and encouraging methods. This success was the main factor responsible for the expeditious dissemination of Islam, either inside or outside the Arab Peninsula. The need and importance of preaching to the chieftains is evident when examining the coming and dissemination of Islam throughout the Malay Archipelago.

One important element seen in the successful preaching carried out by the Prophet SAW on the chieftains was the appropriate use of messages aimed at the target group. It was one of the successful factors in preaching regardless of which approach was used. In order to ascertain the appropriateness of a message in the preaching to the chieftains, their situation or background from several aspects must be first investigated as indicated in the messages contained in the preaching by the Prophet SAW to the chieftains.

Contributors/Acknowledgement: All authors contributed equally to the conception and design of the study. We express our deepest gratitude to Center for Research Excellence \& Incubation Management (CREIM) and Faculty of Islamic Contemporary Studies, Universiti Sultan Zainal Abidin for supporting our intellectual endeavor.

\section{References}

Abu -al-Dahab, A. T. (2002). Mu'jam al-Islami al-Jawanib al-Diniyyah wa al-Siyasiyyah wa alljtima'iyyah wa al-lqtisadiyyah. Al-Qahirah: Dar al-Shuruq.

Abu-Haqah, A. (2007). Mu'jam al-Nafais al-Kabir. Bayrut: Dar al-Nafais.

Ahmad, A. S. (1986). Sulalatus Salatin (Sejarah Melayu). Kuala Lumpur: Dewan Bahasa dan Pustaka.

Al-'Asqalani, I. H. (1989). Fath al-Bari Sharh Sahih al-Bukhari. Bayrut: Dar al-Kutub al-'Ilmiyyah Al-Attas, S. M. N. (2011). Historical Fact And Fiction. Johor Bahru: Universiti Teknologi Malaysia Press.

Al-Bayyanuni, M. (1993). Al-Madkhal ila 'Ilm al-Da'wah, c. 2. Bayrut: Muassasah al-Risalah. Al-Bustani, B. (1869). Qutr al-Muhit. Bayrut: Maktabah Lubnan.

Al-Rumi, M. (2008). Fiqh al-Da'wah fi Sahih al-Imam al-Bukhari. Al-Riyad: Dar Kunuz Ishbiliya. 
Al-Sallabi, A. M. (2004). al-Sirah al-Nabawiyyah 'Ard Waqai' wa Tahlil Ahdath Durus wa 'Ibar, j. 1. Al-Mansurah: Dar al-Yaqin.

Al-Tayyib, B. (1996). Manhaj al-Nabi fi Himayah al-Da'wah wa al-Muhafazah 'ala Munjazatiha Khilal al-Fatrah al-Makkiyyah. Al-Wilayah al-Muttahidah al-Amrikiyyah: al-Ma'had al'Alami li al-Fikr al-Islami.

Arnold, T. W. (1984). The Preaching of Islam, c. 2. Delhi: Renaissance Publishing House.

Aziz, N. N. B. A., \& Mamat, N. (2018). English Teaching Efficacy Enhancement Module (MPEBI) For Early Childhood Education Teachers: Measuring Its Validity Through Experts Viewpoints. International Journal of Academic Research in Progressive Education and Development, 7(4), 447-458

Azmi, W. A. (1980). "Perkembangan Dakwah Islamiah Di Alam Melayu", Isu Dakwah di Malaysia. Selangor: PBMTT.

Barghuth, A. A. (2005). Manahij al-Da'wah fi al-Mujtama' al-Muta'addid al-Adyan wa al-Ajnas. Maliziya: al-Jami'ah al-Islamiyyah al-'Alamiyyah Maliziya.

Fery, I. (2018). The Influence of Information Technology on Application of Accrual Accounting, International Journal of Academic Research in Accounting, Finance and Management Sciences 8 (3): 194-208

Ghalush, A. A. (n.d). al-Da'wah al-Islamiyyah Usuluha wa Wasailuha. Al-Qahirah: Dar al-Kitab alMisr.

Hamka. (1980). Sejarah Umat Islam, c. 3. Kuala Lumpur: Pustaka Antara.

Hamka. (1981). Dari Perbendaharaan Lama. Kuala Lumpur: Pustaka Antara.

Ibn-Hisham. (2004). al-Sirah al-Nabawiyyah, Jamal Thabit et. al. (tahqiq), j. 1. Al-Qahirah: Dar alHadith, h. 235-236.

Kling, Z. (1991). Melayu, Sejarah Dan Kebudayaan Melayu, Jilid Pengenalan. Kuala Lumpur: Dewan Bahasa dan Pustaka.

Legge, J. D. (1972). Indonesia. Kuala Lumpur: Dewan Bahasa dan Pustaka.

Mahayudin, Y. (2001). Islam di Alam Melayu. Kuala lumpur: Dewan Bahasa dan Pustaka.

Mahmud, A. (1993). Figh al-Da'wah ila Allah, j. 1, c. 4. Al-Mansurah: Dar al-Wafa' li al-Tiba'ah wa al-Nashr wa al-Tawzi'.

Nor, H. M. (2007). Jejak Risalah Di Nusantara I. Kuala Lumpur: Pertubuhan Jamaah Islah Malaysia..

Shakir, M. (1991). al-Tarikh al-Islami Qabl al-Bi'thah wa al-Sirah, j. 2, c. 7. Bayrut: al-Maktabah al-Islami.

Yakan, F. (1977). Kayfa Nad'u ila al-Islam, Bayrut: T.P..

Yusoff, Z. (2016). Manhaj dan mesej dakwah kepada pembesar. Kuala Terengganu: Penerbit Universiti Sultan Zainal Abidin.

Zaydan, A. K. (1991). Usul al-Da'wah, c. 4. Baghdad: Maktabah al-Quds.

Zin, A. A. M. (1999). Psikologi Dakwah. Kuala Lumpur: Jabatan Kemajuan Islam Malaysia (JAKIM). 